\title{
Taxation, Corruption and the Exchange Rate Regime
}

\author{
CARSTEN HEFEKER
}

\author{
CESIFO WORKING PAPER NO. 2561 \\ CATEgORY 6: MONETARY Policy and InTERnational Finance \\ FEBRUARY 2009
}
An electronic version of the paper may be downloaded
- from the SSRN website: www.SSRN.com
- from the RePEc website:
- from the CESifo website:
www.RePEc.org
www.CESifo-group.org/wp




\title{
Taxation, Corruption and the Exchange Rate Regime
}

\begin{abstract}
The paper analyzes the relation between institutional quality, such as corruption, in a country and its monetary regime. It is shown that a credibly fixed exchange rate to a low inflation country, like a currency board, can reduce corruption and improve the fiscal system. A monetary union, however, has ambiguous effects. I find that there is convergence between countries with regard to the level of corruption.
\end{abstract}

JEL Code: D72, E63, F33.

Keywords: exchange rate regime, monetary policy, fiscal policy, seigniorage, corruption, developing and transition countries.

\author{
Carsten Hefeker \\ University of Siegen \\ Department of Economics \\ Hoelderlinstrasse 3 \\ 57068 Siegen \\ Germany \\ carsten.hefeker@uni-siegen.de
}

February 2009

I thank Jean-Baptiste Desquilbet, Pierre-Guillaume Méon, Jan-Egbert Sturm and seminar participants in Brussels, Kassel, Munich, Orléans and Zurich for helpful comments. 


\section{Introduction}

Empirical evidence shows a significant contrast concerning the choice of exchange rate regimes by industrialized and developing countries, with emerging markets falling somewhat in between. Whereas industrial countries (with the exception of the member states of the European Union) mostly tend to have floating exchange rates, developing and transition countries often choose fixed exchange rates, at least de facto if not de jure (Calvo and Reinhart 2002, Reinhart and Rogoff 2004, Levy-Yeyati and Sturzenegger 2005). Arguments explaining this difference include the lower credibility of the monetary regime, the shallowness of financial markets, the openness of the country, and the existence of a dominant trading partner or a former colonial tie (for a survey of the arguments, see Rogoff et al. 2004, Meissner and Oomes 2008). Another dimension in which these countries tend to differ is the amount of corruption and the quality of institutions and governance. ${ }^{1}$ Although industrial countries are not immune to these problems, they are clearly more prevalent in developing and transition countries as indices developed by Transparency International (TI 2008) or the World Bank (Kaufmann et al. 2008) show.

In this paper I aim to explore the connection between institutional quality, the fiscal system, and the choice of the exchange rate regime. This connection is important for countries in which monetary policy is dominated by fiscal policy and plays an important role in financing the public budget (Cukierman et al. 1992, Crowe 2006, Catao and Terrones 2005), where de-facto independence of central banks is often not given (Acemoglu et al. 2008), and where corruption and rent-seeking are prevalent phenomena that go hand in hand with high rates of inflation and ambitious government spending (Al-Marhubi 2000, Ades and Di Tella 1999, Blackburn et al. 2008).

The model developed in this paper captures these phenomena and is hence relevant for countries in Africa, the Middle East, Central Asia or the

\footnotetext{
${ }^{1}$ Corruption is only one indicator of bad institutions, and indices show a high correlation of corruption with other indicators of deficient institutional quality.
} 
Caucasus. Many of these countries have considerable amounts of natural resources such as oil or gas, are plagued by widespread corruption and weak institutional capacities, and highly distortive and regressive tax systems.

At the same time, monetary policy institutions are not very credible and for this and other reasons, some of these countries consider forming a monetary union, such as in West Africa (Masson and Pattillo 2005), the Gulf Region (Sturm and Siegfried 2005), or in the former Soviet Union (Chaplygin et al. 2006). ${ }^{2}$ Alternatively, some countries have chosen (or are considering) a unilateral peg to a low inflation anchor currency or the introduction of a foreign currency as a means of payment (see Kenen and Meade 2008 for examples).

The present paper considers the options of monetary autonomy, a hard peg, or a full monetary union and discusses the implications of a move from one regime to another for insitutional quality. I find that a peg to a high inflation country, or a monetary union with such a country, would lower institutional quality in the pegging country. This is because the more seigniorage revenue a country obtains, the less incentive it has to fight against corruption and looting of the budget. A unilateral peg to a low inflation country instead would force fiscal discipline on the pegging country and thus lead the government to fight harder against corruption. However, lower seigniorage also implies higher taxes and can have negative output effects. Governments thus face a trade-off between higher institutional quality with lower inflation versus higher taxes with lower output and government spending.

The paper is structured as follows. Section 2 relates to the literature, while section 3 develops a theoretical model that analyzes the relation between fiscal policy, corruption and inflation. Sections 4-6 look at monetary independence, a tight peg, and a monetary union respectively. Section 7 concludes.

\footnotetext{
${ }^{2}$ There is also discussion about monetary union in Asia or Latin America although plans are much less advanced there (see Kenen and Meade 2008).
} 


\section{The Literature}

The paper is related to three issues so far discussed separately in the literature. One aspect is the connection between fiscal policy and inflation. A well established theory considers inflation and seigniorage revenue as an integral part of an optimal fiscal policy mix (Phelps 1973, Vegh 1989, or Fischer et al. 2002 for a survey). Trying to minimize the welfare costs of distortionary taxation seigniorage is deliberately employed as one source of taxation, in particular when fiscal shocks have to be accounted for (Click 1998). While this theory is a general one, empirical evidence clearly shows that the dominance of monetary policy by fiscal policy is only relevant for developing countries and not for industrial or middle income countries (Catao and Terrones 2005). It is particularly relevant for countries with bad insitutions and low political and social stability (Aisen and Vega 2008).

Clearly, inflation and thus fiscal policy should have an influence on the choice and stability of the exchange rate regime (De Kock and Grilli 1993, Tornell and Velasco 2000). DeKock and Grilli (1993) in a direct extension of the arguments above argue that fixed exchange rates should collapse when fiscal shocks hit that require a increase in spending, whereas Tornell and Velasco (2000) argue that flexible rates impose more fiscal discipline because fixed rates shift the costs of deficits into the future and thus induce reckless fiscal policy.

This literature overlooks a second aspect of fiscal policy, that is, the question of corruption or leakages from fiscal revenue (for a survey, see Aidt 2003). In particular many transition economies and developing countries have a fundamental problem of corruption affecting fiscal revenues, and this, again, is especially the case for resource rich countries (Ades and Di Tella 1999, Blackburn et al. 2008, van der Ploeg 2006). A closely related literature discusses the influence of interest groups on fiscal policy, arguing that powerful interest groups tend to overspend revenues (Lane and Tornell 1996). This effect arises because uncoordinated interest groups do not take into account the external 
effects of their behavior and thus overuse a given resource. Building on that literature, I ask whether a particular exchange rate regime could induce governments to be less tolerant with corruption or other forms of appropriation of fiscal resources.

Finally, there exits a voluminous literature on the connection between monetary policy and institutional quality. This literature, starting with Rogoff (1985), usually focuses on the institutional independence of the central bank or other institutional solutions that lead to a low rate of inflation (see Cukierman 1992 or Siklos 2002). Again, there is evidence that countries with low institutional quality, and in particular with corruption and wide spread rent-seeking, often have a poor monetary policy record (Al-Marhubi 2000).

Most closely related to this paper is recent work by Huang and Wei (2006) who also explore the connection between institutional quality and monetary policy but with a different focus. They analyze the question of the optimal monetary regime more broadly and include the possibility of appointing an independent and conservative central banker. Given deficits in institutional quality in many of these countries, however, internal solutions, such as appointing an independent and conservative central banker or moving to inflation targeting, are not very credible and I therefore focus on external solutions like a peg or a monetary union. ${ }^{3}$ In constrast, I conclude that pegging to a stable anchor currency can lead to lower levels of corruption than monetary autonomy or monetary union.

Another relevant paper, that has a different focus but finds evidence supported by the theory developed here, is Alesina and Wagner (2006). They are interested in the choice of exchange rate regime per se but incidentally find a U-shaped relation between corruption and the degree of exchange rate fixity (measured by the Reinhart-Rogoff 2004 index). While countries

\footnotetext{
${ }^{3}$ Huang and Wei (2006) rightly argue that many countries lack the capacity for inflation targeting but assume at the same time they are able to credibly create independent central banks, thus overlooking the difference between de-facto and de-jure central bank independence (Cukierman 1992, Siklos 2002, Acemoglu et al. 2008).
} 
characterized by good institutions tend to have flexible exchange rates the same is true for countries with very bad institutions. They interpret this as evidence that countries with good institutions can afford to have flexible rates whereas countries with bad institutions need flexible rates. Countries with intermediate levels of institutional quality tend to have more or less rigid exchange rates. Alesina and Wagner (2006), however, do not provide a theory that could explain a causal relationship between these observations. I develop an explanation focused on seigniorage revenue and inflation that is consistent with the empirical evidence on fiscal policy, inflation and bad institutional quality referred to above.

\section{The Model}

The model I use is an extension of the models used by Alesina and Tabellini (1987), De Kock and Grilli (1993), Velasco (1996) or Huang and Wei (2006) among others. The real economy is reflected in an expectation augmented Phillips-curve (with slope $\alpha<1$ ), where output can be increased by inflation above its expected value $\pi_{i}>\pi_{i}^{e}$ and is lowered by distortive taxation $\tau_{i} \cdot{ }^{4}$ In addition, output is affected by an exogenous supply shock $\varepsilon_{i}$ with $E\left[\varepsilon_{i}\right]=0$ and $E\left[\varepsilon_{i}^{2}\right]=\sigma^{2}$. All variables are expressed in logarithms. Thus, output in country $i$ follows

$$
y_{i}=\alpha\left(\pi_{i}-\pi_{i}^{e}-\tau_{i}\right)-\varepsilon_{i}
$$

The budget constraint comprises distortionary taxation and revenue from inflation (seigniorage) as main sources of revenue. The government benefits, depending on the exchange rate and monetary system, from seigniorage revenue that is transferred from the central bank to the budget. The contribu-

\footnotetext{
${ }^{4}$ Alesina and Tabellini derive the negative influence of taxation on output from a standard profit maximization approach of firms. Government spending does not have a (net) positive influence on output and is thus unproductive. Again, this assumption applies best to countries with low institutional quality.
} 
tion of inflation to the budget is measured as $s .{ }^{5}$

Extending the standard model, I also assume the government benefits from some exogenous income stream, $\kappa_{i} \geq 0$, that might be thought of as revenue from natural resources, such as oil, gas, diamonds or gold. ${ }^{6}$ This allows introducing aspects important for many developing and transition economies with considerable amounts of natural resources at their disposal.

Tax revenue, to be determined by the government, is $\tau_{i} . \theta_{i}$ measures the impact of theft, corruption or the institutional quality more broadly on the budget. Corrupt officials (or parts of the government) may be bribed into not collecting all tax obligations by underreporting profits of firms, they may steal part of the revenue, or could divert funds for personal purposes and prestige objects. ${ }^{7}$ Finally, it could also reflect the access of uncoordinated interest groups to the budget.

Notice that in contrast to Huang and Wei (2006), I do not assume that corruption is a share of tax revenue but an absolute sum that can, because of $\kappa_{i}$, even be larger than tax revenue $\tau_{i}$, since corruption need not only reduce tax revenue but may in addition divert a part of the exogenous revenue stream from natural resources into private pockets (Lane and Tornell 1996).

Summarizing, the budget constraint is

$$
g_{i}=\kappa_{i}+\tau_{i}-\theta_{i}+s \pi_{i}
$$

There are three players: the private sector, the central bank and the government. The private sector forms rational expectations about the rate

\footnotetext{
${ }^{5}$ A fully or nearly fully dollarized economy would thus have $s$ close to zero. In fact, one could argue that eventually $s$ becomes negative with very high rates of inflation (Fischer et al. 2001). For simplicity, I assume $s$ constant; not much would change by modelling $s$ as a declining function of $\pi$ (Huang and Wei 2006).

${ }^{6}$ Alternatively, this can be thought of as non-distortionary taxation.

${ }^{7}$ Corruption is only a shorthand expression for all forms of expropriation of official funds. This can be by the bureaucracy, government ministers, managers of publicly owned resource extraction industries, or anybody else with access to public funds. See Aidt (2003) or Blackburn et al. (2008) for an extensive discussion of how corruption leads to revenue leakages.
} 
of inflation and is otherwise passive. Government and central bank are two independent actors. This could either reflect some degree of independence of the central bank or describe a conflict between different entities of the government, such as between the ministry of finance and the central bank. All players play Nash against each other, so fiscal policy, monetary policy, expectations and anti-corruption measures are all set non-cooperatively. The timing is: (i) institutional quality (or corruption) is set by the government, (ii) the private sector forms expectations about inflation and taxes, (iii) the exogenous shock occurs, (iv) taxes are set, (v) inflation is set, and (vi) output is realized.

Like it is standard in the literature (Barro and Gordon 1983, Rogoff 1985), I assume that the central bank is concerned with avoiding deviations of inflation from zero and stabilizing output, where the (log of) the natural level of output is assumed to be zero. ${ }^{8}$ The degree of conservatism of the central bank is $c$. Then, the central bank's objective function is given as

$$
L_{i}=c \pi_{i}^{2}+y_{i}^{2}
$$

The government is supposed to be under the influence of several important interest groups in the economy so that it aims simultaneously at stabilizing output and inflation, as well as meeting a spending target. The spending target $\bar{g}_{i}$ reflects standard political economy arguments about reelection motives, interest group pressure or simply the absence of alternative instruments to increase political support (see Brender and Drazen 2005 or Demertzis et al. 2004). In addition the government in concerned with corruption (or leakages of fiscal revenue). Changes to the given level of corruption $\widehat{\theta}_{i}$ are assumed

\footnotetext{
${ }^{8}$ Huang and Wei (2006), using Alesina and Tabellini's (1987) approach, assume that the central bank is also concerned with stabilizing government spending around its target value which leads to an inflation bias of monetary policy. Since it is not obvious why central banks should be concerned with spending targets, I use the standard formulation. In addition, in Huang and Wei's setup with identical utility functions, there is no difference between a cooperative and non-cooperative game. My formulation allows for conflicts between policy makers because the government has an additional target.
} 
to be costly in political terms. ${ }^{9}$ Increasing corruption might result in protest from the population, lower foreign investment or less support from international financial organizations, like the World Bank and the International Monetary Fund. A reduction in corruption, in contrast, leads to personal income losses for the government or to loss of support from former beneficiaries of corruption. Thus, I assume that corruption can be reduced by increasing the control of public servants, by reducing the influence of interest groups and rent-seeking, and by creating better institutions like setting up independent courts or improving public administration. But because of the personal or political costs of fighting corruption, changes in either direction from the given level are (politically) costly so that $C\left(\theta_{i}\right)=\gamma\left(\theta_{i}-\widehat{\theta}_{i}\right)^{2}$.

The government's objective function is thus

$$
V_{i}=c \pi_{i}^{2}+y_{i}^{2}+b\left(g_{i}-\bar{g}_{i}\right)^{2}+C\left(\theta_{i}\right)
$$

Recall that I assume that $\theta_{i}$ is chosen before taxation. Governments, because they can control corruption to some degree, consider fighting corruption as an alternative to increasing taxation and thus optimize between fighting corruption and increasing taxation. The difference is that taxation is more flexible and can be adjusted in response to shocks.

\section{Taxes and Corruption With Independent Monetary Policy}

One possible choice of the government is to choose flexible exchange rates which allows to set monetary policy independently. Assuming that the central bank is independent enough not to be a direct instrument of the government, the two national players choose their optimal policies in a non-

\footnotetext{
${ }^{9}$ More precisely, $\theta_{i}$ is the impact of corruption on the budget. For simplicity, I will speak of the level of corruption in what follows so that $\widehat{\theta}_{i}$ is the initial level of corruption.
} 
cooperative game. ${ }^{10}$

I begin by describing the choice of the central bank. Its optimal policy follows form minimizing (3) as $\pi_{i}=\frac{\alpha}{\alpha^{2}+c}\left(\alpha\left(\tau_{i}+\pi_{i}^{e}\right)-\varepsilon_{i}\right){ }^{11}$ Monetary policy thus responds to minimize the negative output effects of taxation, as well as to expected inflation and economic shocks.

Turning to the policy choices of the government, optimization of (4) with respect to fiscal policy and corruption yield $\tau_{i}=\frac{b\left(\Delta_{i}+\theta_{i}-s \pi_{i}\right)+\alpha^{2}\left(\pi_{i}-\pi_{i}^{e}\right)-\alpha \varepsilon_{i}}{\alpha^{2}+b}$ and $\theta_{i}=\frac{\gamma \widehat{\theta}_{i}+b\left(\tau_{i}^{e}+s \pi_{i}^{e}-\Delta_{i}\right)}{\gamma+b}$ with $\Delta_{i} \equiv \bar{g}_{i}-\kappa_{i}$. The two first-order conditions show that taxation and corruption are strategic complements. A high tax revenue leads government to allow more corruption and vice versa.

Solving these equation simultaneously, yields taxation under monetary autonomy (indexed N) as

$$
\tau_{i}^{N}=\frac{c b \gamma\left(\Delta_{i}+\widehat{\theta}_{i}\right)}{c\left(\gamma\left(\alpha^{2}+b\right)+\alpha^{2} b\right)+\alpha^{2} b \gamma s}-\frac{\alpha(c+b s) \varepsilon_{i}}{\alpha^{2}(c+b s)+b\left(\alpha^{2}+c\right)}
$$

Structural taxation is increasing in the difference between spending targets and exogenous revenue $\Delta_{i}$ and in initial corruption $\widehat{\theta}_{i}$. An ambitious spending target increases taxation (and thus distortions in the real economy), and so does high corruption. Taxation is falling in the contribution of seigniorage to the budget, measured by $s$, and is increasing in $c$, the central bank's conservatism because $c$ lowers inflation and seigniorage. Moreover, since taxation has a negative influence on output, the government will adjust taxation in reaction to shocks.

\footnotetext{
${ }^{10} \mathrm{~A}$ conflict between central bank and government does not necessarily imply that the central bank is fully and credibly independent (see Lohmann 1992).

${ }^{11}$ Huang and Wei (2006) assume that the central bank is able to commit its monetary policy so that always $\pi=\pi^{e}$. There is thus no credibility gain which is arguably the main argument for developing countries to peg.
} 
Corruption is allowed to be

$$
\theta_{i}^{N}=\frac{\gamma \widehat{\theta}_{i}\left(c\left(\alpha^{2}+b\right)+\alpha^{2} b s\right)-\alpha^{2} b c \Delta_{i}}{c\left(\gamma\left(\alpha^{2}+b\right)+\alpha^{2} b\right)+\alpha^{2} b \gamma s}
$$

which is falling in $\Delta_{i}$, meaning that a higher spending target induces more efforts to fight corruption, and increasing in initial corruption $\widehat{\theta}_{i}$. The higher is the resource revenue $\kappa_{i}=\Delta_{i}-\bar{g}_{i}$, the more corruption will be allowed, as is frequently observed in resource rich countries (van der Ploeg 2006, Bornhorst et al. 2008). $\theta_{i}^{N}$ is increasing in $s$ if $\widehat{\theta}_{i}>\Delta_{i}$, and decreasing in $c$, reflecting that central bank independence and good institutional quality are positively correlated. The more conservative is the central bank the more efforts the government will undertake to lower corruption and other forms of leakages because it can expect only little contribution from seigniorage to the budget.

With rational expectation of the private sector, expected inflation is $\pi_{i}^{e}=$ $\frac{\alpha^{2}}{c} \tau_{i}$, leading to a rate of inflation of

$$
\pi_{i}^{N}=\frac{\alpha^{2} b \gamma\left(\Delta_{i}+\widehat{\theta}_{i}\right)}{c\left(\gamma\left(\alpha^{2}+b\right)+\alpha^{2} b\right)+\alpha^{2} b \gamma s}+\frac{\alpha b \varepsilon_{i}}{\alpha^{2}(c+b s)+b\left(\alpha^{2}+c\right)}
$$

The more inflation averse is the central bank the lower is the reaction to fiscal policy and thus inflation. ${ }^{12}$ At the same time, a more conservative central bank will stabilize less (Rogoff 1985). Like taxation, inflation is composed of two parts: a structural part (the first term) and the reaction to shocks (second term). In general, inflation and taxation will move into opposite directions in response to shocks.

\footnotetext{
${ }^{12}$ As indicated above, assuming that the central bank is concerned with a spending target would additionally increase inflation due to the bank's intention to contribute to financing these expenditures. Here, inflation is increasing in taxation because the central bank compensates for the negative output effect of taxes.
} 


\section{A Unilateral Exchange Rate Peg}

One alternative to independent monetary policy, frequently chosen by developing and transition countries to solve persistent credibility problems, is an exchange rate peg (Calvo and Reinhart 2002, Reinhart and Rogoff 2004, Rogoff et al. 2004). There are many forms of pegs, of course, but I focus on the subgroup of very hard peg, such as dollarization and currency boards. Intermediate regimes with limited flexibility provide a combination of peg and flexible rate and are often chosen by more advanced developing and transition countries (Frankel 1999). However, intermediate pegs are less credible than hard pegs, which is particularly relevant for countries plagued by high levels of corruption and weak institutions (Hinds 2006, Litan and Steil 2006). The difference to the case of monetary union, to be considered in the next section, is that the central bank of the anchor country does not take developments in the pegging country into account. Hence, inflation is completely exogenous for the pegging country and there is no reaction of monetary policy to shocks in this country Instead, the pegging imports the monetary reaction to shocks in the anchor country.

Denoting inflation in the anchor country as $\widehat{\pi}$, the government's choice of taxation and corruption tolerated under a hard peg (indexed P) are

$$
\tau_{i}^{P}=\frac{b \gamma\left(\Delta_{i}+\widehat{\theta}_{i}-s \widehat{\pi}\right)}{\gamma\left(\alpha^{2}+b\right)+\alpha^{2} b}-\frac{\alpha \varepsilon_{i}}{\alpha^{2}+b}
$$

and

$$
\theta_{i}^{P}=\frac{\gamma\left(\alpha^{2}+b\right) \widehat{\theta}_{i}-\alpha^{2} b\left(\Delta_{i}-s \widehat{\pi}\right)}{\gamma\left(\alpha^{2}+b\right)+\alpha^{2} b}
$$

For all practical purposes, it can be assumed that inflation in the anchor country is so low that the contribution of seigniorage to the budget at this rate of inflation is negligible. I therefore set $\widehat{\pi}=\pi_{i}^{P}=0$ in what follows. ${ }^{13}$ This

\footnotetext{
${ }^{13}$ This may of course be different for a country that unilaterally pegs to another developing or transition country. Since most pegs are to the dollar or the euro, however, I
} 
implies that I cannot distinguish between a very tight peg, such as a currency board, and full dollarization. While the former, in principle, implies at least some seigniorage revenue as long as the anchor currency's rate of inflation is positive, this is not the case with dollarization. ${ }^{14}$

Comparing monetary autonomy and pegging (see Appendix B), the following proposition can be established:

Proposition 1 Under a unilateral hard peg more taxation, lower output, lower inflation, lower spending, and lower corruption can be expected than under monetary autonomy. Since economic shocks can no longer be stabilized, taxtation, output, and government spending become more volatile.

Because the government loses seigniorage the budget constraint becomes harder, forcing the government to look for alternative sources of finance and to lower overall spending. There are two sources to make up for the loss of seigniorage, taxation and fighting corruption. Because of increasing marginal costs both are used. Due to the higher rate of taxation, output will be lower on average and more variable because monetary policy does not stabilize. Since there is no seigniorage under the peg, government spending will be lower as well. Finally, taxation must become more flexible and if $\alpha^{2}>b s$ taxation will react stronger in response to shocks than under autonomy.

\section{Monetary Union}

The case of a monetary union is more complicated. I assume there are two countries in the monetary union with relative share $z_{i}$ so that $z_{1}+z_{2}=1 .^{15}$

neglect this case.

${ }^{14}$ The advantage of full dollarization instead might be that interest rates are lower because reneging on the peg is less likely. Since there is no role for interest rates in my model, this effect is neglected here.

${ }^{15}$ One may also assume a union of $n$ countries with $z_{1}=\frac{1}{n} z_{i}$ and $z_{2}=\frac{1}{n-1} \sum z_{j}$ as the average of all other countries in the union. 
Since I am interested in the situation of the individual country, which is likely to be rather small in comparison to the rest of the monetary union, I focus on country 1 and assume $z_{2}>z_{1}$. This reflects, for instance, a monetary union between a large and a small country, such as discussed between Russia and individual CIS countries, or the case of a single country joining an existing monetary union. As Chaplygin et al. (2006) argue it is even possible that $z_{1}=0$ and that the smaller country plays no role in determining monetary policy. The difference to a unilateral peg, however, is that some seigniorage revenue is distributed to the country. I assume that the share of each country in overall seigniorage corresponds to its relative economic size $z_{i}$.

In a Nash-game with symmetric countries it is obvious that the policy choices of a single country are equal to the average and vice versa. Thus, the comparison is only interesting if countries diverge in some characteristics. In order to focus on economic differences, I assume $\Delta_{1} \lessgtr \Delta_{2}$ and $\widehat{\theta}_{1} \lessgtr \widehat{\theta}_{2}$ while all utility parameters are equal across countries. (It is rather trivial to derive economic consequences of different preferences. Moreover, higher or lower preferences for corruption lead to the same effect as a higher initial level of corruption.)

The central bank's objective function in the monetary union (indexed M) is

$$
L^{M}=c \pi^{2}+b\left(z_{1} y_{1}+z_{2} y_{2}\right)^{2}
$$

where I assume that inflation is equal across the monetary union. ${ }^{16}$ The common central bank is concerned with minimizing common inflation and stabilizing average output in the union. The first order condition with respect

\footnotetext{
${ }^{16}$ For simplicity I assume a common rate of inflation. Because of transmission asymmetries or the Balassa-Samuelson effect inflation rates can differ between countries. Since these differences are indepedent from monetary policy, however, I neglect them. Economically, the absence of structural differences in inflation supposes countries which are roughly equally developed.
} 
to inflation is

$$
\pi^{M}=\frac{\alpha^{2}}{\alpha^{2}+c}\left(\pi^{e}+z_{1} \tau_{1}+z_{2} \tau_{2}\right)+\frac{\alpha}{\alpha^{2}+c}\left(z_{1} \varepsilon_{1}+z_{2} \varepsilon_{2}\right)
$$

Thus, the only difference between the reaction of the national central bank and the union's central bank is that the latter takes developments in both countries into account and weighs each country with its relative economic weight $z_{i}$. Since I abstract from structural differences in the rate of inflation, expected inflation is equal in both economies. For simplicity, I further assume that national shocks are uncorrelated and independent.

As Appendix A demonstrates, as before taxation is increasing in the structural spending gap and initial corruption in a country. However, it is falling in the spending gap and corruption in the other countries while the strength of this reaction depends on the relative size of that country $z_{2}$. This is because these influences give rise to higher inflation and thus increase seigniorage.

Moreover, as before the country lowers taxation in response to an exogenous shock. Since the central bank will also react to this shock, there are two opposing effects. If the output effect of inflation is large, government can let taxation increase because its negative output consequences are compensated by inflation. Taxation falls, however, if seigniorage is increasing sufficiently as a consequence of monetary expansion. Hence, it matters whether $\alpha^{2}>b s$.

Corruption is increasing in the initial level and decreasing in the spending gap, like in the case of monetary independence. It is additionally increasing in seigniorage revenue which in turn is a function of spending gaps and initial corruption in both countries. Hence, corruption levels in member countries are complements. Because corruption is determined before shocks, it is independent from shocks and time invariant.

As argued in the introduction, there are at least two possibilities to move to a monetary union. Countries can jump directly from monetary autonomy to a union or have a peg to another currency before they join a union. I consider both cases in turn. 
Comparing first the results for monetary union with the results under monetary autonomy leads to the following proposition (see Appendix B):

Proposition 2 Moving from autonomy to an asymmetric monetary union, corruption will increase if $\Delta_{2}+\widehat{\theta}_{2}>\Delta_{1}+\widehat{\theta}_{1}$. Moreover, it can be expected that taxes will decrease, that output will increase (because taxation is lowered), and that inflation and spending (because of higher seigniorage) will increase. If $\alpha^{2}>$ bs and $\varepsilon_{1}>\varepsilon_{2}$, there is less stabilization through monetary policy in the monetary union and more stabilization of shocks through taxes.

Monetary union will not necessarily have beneficial structural effects for all countries. If the other member country brings a large finance gap and a high degree of corruption into the monetary union, inflation set by the common central bank will be relatively high. Thus, seigniorage will be higher for the home country than before which induces the government to let corruption increase and to lower domestic taxation. This negative effect from monetary union is, of course, increasing in the relative weight of the partner country $z_{2}$. There is hence a convergence between countries; countries with a high initial level of distortions will lose seigniorage and thus lower corruption and spending and vice versa.

As compared to stabilization of shocks through monetary policy and taxation, it is clear that taxes stabilize less if monetary policy stabilizes more. If $\varepsilon_{1}>\varepsilon_{2}$ the common central bank reacts less strongly to shocks in the home country than the national central bank before monetary union, forcing domestic taxation into this role. Moreover, $\alpha^{2}>b s$ implies that monetary policy is predominantly used to stabilize shocks (in comparison to being used to finance government spending). This implies that under monetary autonomy this instrument has been used relatively strongly. Hence, both aspects together imply that there is less stabilization through monetary policy than under monetary autonomy.

Comparing instead the tight peg to the monetary union yields the following results (see Appendix B): 
Proposition 3 If a country moves from a tight peg to an asymmetric monetary union with a more distorted partner country $\Delta_{2}+\widehat{\theta}_{2}>\Delta_{1}+\widehat{\theta}_{1}$, corruption will increase. In addition, on average taxes will decrease, whereas inflation, the level of spending, and the level of output will increase. The response of taxes to shocks is lower under monetary union if $\alpha^{2}>$ bs while that of monetary policy increases. Output and government spending are more variable under the peg.

Since by definition the peg is accompanied by zero inflation and no seigniorage, it is clear that inflation increases in the monetary union, while taxation will decrease. Due to higher seigniorage revenue, the government will allow corruption and government spending to increase. Because of lower taxation output will also increase. Thus, countries that are considering moving from a unilateral peg to an asymmetric monetary union with distorted countries risk seeing their institutional qualities deteriorate. Moreover, since monetary policy cannot react to shocks under the peg, taxes will have to be used for stabilization of shocks, leading to more volatile output and spending.

\section{Conclusion}

The paper has analyzed a relatively little researched dimension of institutional quality and monetary policy. While the existence of independent and conservative central banks has often been explored in comparison to external anchors for monetary policy, the influence of fiscal policy and corruption and rent-seeking is under-explored. I develop a model that explicitly considers the connection between fiscal policy and monetary policy if corruption and other leakages from fiscal revenue are important. It is shown that a tight peg to a low inflation currency can improve the institutional quality in a country. The government is induced to fight more strongly against leakages and corruption if the revenue from seigniorage is lowered. This, unfortunately, also leads to higher taxation and thus higher output distortions. Governments 
thus face a trade-off between higher revenue, output and spending and lower inflation and corruption when choosing their exchange rate regime. The effects of changes in taxation and corruption on government utility are thus not obvious and will depend on the relative weights a government assigns to these opposing influences. Which of the regimes is preferred by a government mainly depends on the initial level of distortions and corruption and the relative preference for reducing inflation, stabilizing output and expenditures, and fighting corruption.

Concerning the stabilizing role of monetary policy it is clear that a hard peg implies the least stabilization whereas in a monetary union member countries import monetary reactions to shocks in partner countries (according to their relative weights). The loss of monetary policy implies that fiscal policy will have to assume a stronger role in stabilization which implies a higher volatility of taxes and output. This as well can be considered a disadvantage of giving up monetary autonomy.

Moving to a full monetary union can lead to more or less corruption, depending mainly on the choice of partner countries for the monetary union. Countries with different levels of corruption and spending targets for fiscal policy will experience a convergence in corruption and spending. Thus, lower corruption will only result if the country joins a monetary union where is has a relatively little weight and where the other countries have relatively well developed institutions.

These results, although not tested directly in this paper, are supported by the evidence in other studies. There is a strong correlation between corruption and fiscal problems, and also between inflation and corruption, thus supporting the view that seigniorage plays an important role in developing and middle income countries. It is also well established in the literature that with access to "easy" fiscal revenues governments have lower incentives to fight against corruption. Moreover, it is clear that high rates of inflation are ultimately not compatible with fixed rates. Thus, fixed rates are nei- 
ther compatible with weak institutions and corruption as these imply higher inflation.

These results have obvious implications for countries in a high corruption environment, such as in Africa or the CIS states. Since some of these countries are considering one or the other form of monetary integration with dominant neighbors, the results derived here suggest being careful. It might be better in some cases to (continue to) peg to currencies like the US-dollar or the euro instead of moving to a regional monetary union. These findings also cast doubt on the now nearly universal advice by international agencies like the International Monetary Fund that countries choose flexible exchange rate regimes. Such a solution may actually be accompanied by a deterioration of institutional quality which is also one of the aims of international organizations. It should be taken into consideration that these aims need not necessarily go together well.

\section{Appendix}

\section{Appendix A: Taxes and Corruption in Monetary Union}

Taking the first order conditions for the government from (4), using the rate of inflation (11), imposing rational expectations, and solving simultaneously for taxation and corruption, the equilibrium tax rate in country 1 under 
monetary union is

$$
\begin{gathered}
\tau_{1}^{M}=\frac{c \gamma b\left(\Delta_{1}+\widehat{\theta}_{1}\right)}{c\left(\gamma\left(\alpha^{2}+b\right)+\alpha^{2} b\right)+\alpha^{2} \gamma b s} \\
\quad+\gamma b \frac{s \gamma b \alpha^{2} z_{2} \cdot\left(\Delta_{1}+\widehat{\theta}_{1}-\Delta_{2}-\widehat{\theta}_{2}\right)}{\left(\gamma\left(\alpha^{2}+b\right)+\alpha^{2} b\right)\left[c\left(\gamma\left(\alpha^{2}+b\right)+\alpha^{2} b\right)+\alpha^{2} \gamma b s\right]} \\
\quad+\frac{\alpha b\left(\alpha^{2}-b s\right)\left(z_{1} \varepsilon_{1}+z_{2} \varepsilon_{2}\right)}{\left(\alpha^{2}+b\right)\left(b\left(\alpha^{2}+c\right)+\alpha^{2}(c+b s)\right)}-\frac{\alpha \varepsilon_{1}}{\alpha^{2}+b}
\end{gathered}
$$

The level of corruption is

$$
\begin{aligned}
\boldsymbol{\theta}_{1}^{M}=\frac{\gamma\left(\alpha^{2}+b\right) \widehat{\theta}_{1}-\alpha^{2} b \Delta_{1}}{\gamma\left(\alpha^{2}+b\right)+\alpha^{2} b} & \\
& +\frac{\left(\alpha^{2} b\right)^{2} s \gamma \cdot\left[z_{1}\left(\Delta_{1}+\widehat{\theta}_{1}\right)+z_{2}\left(\Delta_{2}+\widehat{\theta}_{2}\right)\right]}{\left(\gamma\left(\alpha^{2}+b\right)+\alpha^{2} b\right) \cdot\left[c\left(\gamma\left(\alpha^{2}+b\right)+\alpha^{2} b\right)+\alpha^{2} \gamma b s\right]}
\end{aligned}
$$

From this, inflation follows as

$$
\pi^{M U}=\frac{\alpha^{2} b \gamma\left[z_{1}\left(\Delta_{1}+\widehat{\theta}_{1}\right)+z_{2}\left(\Delta_{2}+\widehat{\theta}_{2}\right)\right]}{c\left(\gamma\left(\alpha^{2}+b\right)+\alpha^{2} b\right)+\alpha^{2} \gamma b s}+\frac{\alpha b\left(z_{1} \varepsilon_{1}+z_{2} \varepsilon_{2}\right)}{b\left(\alpha^{2}+c\right)+\alpha^{2}(c+b s)}
$$

\section{Appendix B: Comparison of Monetary Regimes}

When comparing results under different regimes, two effects have to separated for inflation and taxation. Because both also respond to shocks, optimal policy can be separated into a structural effect (corresponding to expected values) and the response to shocks. I will thus separate comparisons into a structural part and a part capturing the response to economic shocks.

It is therefore useful to realize that taxation and inflation can be rewritten as $, \tau_{i}^{N}=E\left[\tau_{i}^{N}\right]-\frac{\alpha(c+b s) \varepsilon_{i}}{\alpha^{2}(c+b s)+b\left(\alpha^{2}+c\right)}, \pi_{i}^{N}=E\left[\pi_{i}^{N}\right]+\frac{\alpha b \varepsilon_{i}}{b\left(\alpha^{2}+c\right)+\alpha^{2}(c+b s)}, \tau_{i}^{P}=$ 
$E\left[\tau_{i}^{P}\right]-\frac{\alpha \varepsilon_{i}}{\alpha^{2}+b}, \pi_{i}^{P}=E\left[\pi_{i}^{P}\right]=0, \tau_{1}^{M}=E\left[\tau_{1}^{M}\right]+\frac{\alpha b\left(\alpha^{2}-b s\right)\left(z_{1} \varepsilon_{1}+z_{2} \varepsilon_{2}\right)}{\left(\alpha^{2}+b\right)\left(b\left(\alpha^{2}+c\right)+\alpha^{2}(c+b s)\right)}-\frac{\alpha \varepsilon_{1}}{\alpha^{2}+b}$ and $\pi^{M}=E\left[\pi^{M}\right]+\frac{\alpha b\left(z_{1} \varepsilon_{1}+z_{2} \varepsilon_{2}\right)}{b\left(\alpha^{2}+c\right)+\alpha^{2}(c+b s)}$.

Moreover, one can rewrite government spending and output as functions of inflation and taxation: $y_{i}^{k}=\frac{\alpha}{\alpha^{2}+b}\left(b\left(\pi_{i}^{k}-E\left[\pi_{i}^{k}\right]\right)-\left(\alpha^{2}+b\right) E\left[\tau_{i}^{k}\right]\right)-$ $\frac{b}{\alpha^{2}+b} \varepsilon_{i}$ and $g_{i}^{k}=\bar{g}_{i}-\frac{\gamma \alpha^{2}}{\gamma\left(\alpha^{2}+b\right)+\alpha^{2} b}\left(\Delta_{i}+\widehat{\theta}_{i}-s \pi_{i}^{k}\right)-\frac{\alpha \varepsilon_{i}}{\alpha^{2}+b}+\left(\pi_{i}^{k}-E\left[\pi_{i}^{k}\right]\right)$. $\left(\frac{\alpha^{2}}{\alpha^{2}+b}+\frac{s b\left(\alpha^{2}+\gamma\right)}{\gamma\left(\alpha^{2}+b\right)+\alpha^{2} b}\right)$, where $k$ refers to the monetary regime, $k=N, P, M$.

\section{National Autonomy (N) vs. Peg (P)}

Comparing (6) and (9) it is straightforward to find $\theta_{i}^{N}>\theta_{i}^{P}$ will always hold. Turning to taxation, one finds that structural (or expected) taxation is always higher under the peg, thus $E\left[\tau_{i}^{P}\right]>E\left[\tau_{i}^{N}\right]$ by using (5) and (8). Therefore, expected output will decrease while government spending will increase. Taxation will react stronger to the shock under the peg if $\frac{\alpha \varepsilon_{i}}{\alpha^{2}+b}>\frac{\alpha(c+b s) \varepsilon_{i}}{\alpha^{2}(c+b s)+b\left(\alpha^{2}+c\right)}$ which is the case if $\alpha^{2}>b s$. This is because there is no monetary support to deal with the shock under the peg. Inflation under autonomy will be higher by definition and so will be the response to the shock. Because of the higher rate of taxation, average output will be lower and become more volatile. Since there is no seigniorage under the peg, government spending will be lower as well.

\section{National Autonomy (N) vs. Monetary Union (M)}

Comparing autonomy and monetary union, one finds $\theta_{1}^{M}>\theta_{1}^{N}, E\left[\tau_{1}^{N}\right]>$ $E\left[\tau_{1}^{M}\right]$ and $E\left[\tau_{1}^{M}\right]>E\left[\tau_{1}^{N}\right]$ if and only if $\Delta_{2}+\widehat{\theta}_{2}>\Delta_{1}+\widehat{\theta}_{1}$. In this case, expected output and spending will increase because inflation increases and taxation falls under monetary union.

Moreover, there will be less stabiliaztion of shocks through inflation and thus necessarily more stabilization through taxation under monetary union if $\varepsilon_{1}>\varepsilon_{2}$ and $\alpha^{2}>b s$. 


\section{Peg (P) vs. Monetary Union (M)}

Comparing the peg and monetary union shows $\theta_{i}^{M}>\theta_{i}^{P}$ always holds. One also finds that $\tau_{i}^{P}=E\left[\tau_{i}^{P}\right]-\frac{\alpha \varepsilon_{i}}{\alpha^{2}+b}>\tau_{1}^{M}=E\left[\tau_{1}^{M}\right]+\frac{\alpha b\left(\alpha^{2}-b s\right)\left(z_{1} \varepsilon_{1}+z_{2} \varepsilon_{2}\right)}{\left(\alpha^{2}+b\right)\left(b\left(\alpha^{2}+c\right)+\alpha^{2}(c+b s)\right)}-$ $\frac{\alpha \varepsilon_{1}}{\alpha^{2}+b}$. Taxation will directly respond to the shock by the same amount $\frac{\alpha \varepsilon_{1}}{\alpha^{2}+b}$ which thus cancels. It is also easy to find that $E\left[\tau_{i}^{P}\right]>E\left[\tau_{1}^{M}\right]$ and that thus structural taxation will be higher under a peg. As before, because taxes are higher under the peg output falls and becomes more variable. Likewise, average government spending is higher under monetary union due to seigniorage revenue.

The response of taxes to shocks is muted under monetary union if $\alpha^{2}>b s$ because in this case the government lets monetary policy respond of the shock and stabilizes less through taxation.

\section{References}

[1] Acemoglu, Daron, Simon Johnson, Pablo Querubin and James A. Robinson (2008), When Does Policy Reform Work: The Case of Central Bank Independence, Brookings Papers on Economic Activity, forthcoming.

[2] Ades, Alberto and Rafael Di Tella (1999) Rents, Competition and Corruption, American Economic Review 89, 982-993.

[3] Aidt, Toke (2003) Economic Analysis of Corruption: A Survey, Economic Journal 113, F632-F652.

[4] Aisen, Ari and Francisco José Vega (2008) The Political Economy of Seigniorage, Journal of Development Economics 87, 29-50.

[5] Alesina, Alberto and Guido Tabellini (1987) Rules and Discretion with Noncoordinated Monetary and Fiscal Policies, Economic Inquiry 25, 619-630. 
[6] Alesina, Alberto and Alexander Wagner (2006) Choosing (and Reneging On) Exchange Rate Regimes, Journal of the European Economic Association 4, 770-799.

[7] Al-Marhubi, Fahim (2000) Corruption and Inflation, Economics Letters 66, 199-202.

[8] Barro, Robert and David Gordon (1983) A Positive Theory of Monetary Policy in a Natural Rate Model, Journal of Political Economy 91, 589610.

[9] Blackburn, Keith, Kyriakos Neandis and Emranul Haque (2008) Corruption, Seigniorage and Growth: Theory and Evidence, CESifo Working Paper 2354.

[10] Bornhorst, Fabian, Sanjeev Gupta and John Thornton (2008) Natural Resource Endowments, Governance, and the Domestic Revenue Effort: Evidence from a Panel of Countries, IMF Working Paper 08/170.

[11] Brender, Adi and Allan Drazen (2005) Political Budget Cycles in New versus Established Democracies, Journal of Monetary Economics 52, 1271-1295.

[12] Calvo, Guillermo and Carmen Reinhart (2002) Fear of Floating, Quarterly Journal of Economics 117, 379-408.

[13] Catao, Luis and Marco Terrones (2005) Fiscal Deficits and Inflation, Journal of Monetary Economics 52, 529-554.

[14] Chaplygin, Vladimir, Andrew Hughes Hallett and Christian Richter (2006) Monetary Integration in the Ex-Soviet Union: A "Union of Four"?, Economics of Transition 14, 47-68.

[15] Click, Reid (1998) Seigniorage in a Cross-Section of Countries, Journal of Money, Credit and Banking 30, 154-171. 
[16] Crowe, Christopher (2006) Inflation, Inequality and Social Conflict, IMF Working Paper 06/158.

[17] Cukierman, Alex (1992) Central Bank Strategy, Credibility, and Independence, Cambridge: MIT Press

[18] Cukierman, Alex, Sebastian Edwards and Guido Tabellini (1992) Seigniorage and Political Instability, American Economic Review 82, 537-555.

[19] De Kock, Gabriel and Vittorio Grilli (1993) Fiscal Policies and the Choice of Exchange Rate Regime, Economic Journal 103, 347-358.

[20] Demertzis, Maria, Andrew Hughes Hallett and Nicola Viegi (2004) An Independent Central Bank Faced with Elected Governments, European Journal of Political Economy 20, 907-922.

[21] Fischer, Stanley, Ratna Sahay and Carlos Vegh (2002) Modern Hyperand High Inflations, Journal of Economic Literature 40,837-880.

[22] Frankel, Jeffrey (1999) No Single Currency Regime is Right for All Countries at All Times, Essays in International Finance 215, Princeton University.

[23] Hinds, Manuel (2006) Playing Monopoly with the Devil: Dollarization and Domestic Currencies in Developing Countries, New Haven: Yale University Press.

[24] Huang, Haizhou and Shang-Jin Wei (2006) Monetary Policies for Developing Countries: The Role of Institutional Quality, Journal of International Economics 70, 239-252.

[25] Kaufmann, Daniel, Aart Kraay and Massimo Mastruzzi (2008) Governance Matters VII: Governance Indicators for 1996-2007, World Bank Policy Research Working Paper No. 4654. 
[26] Kenen, Peter and Ellen Meade (2008) Regional Monetary Integration, Cambridge: Cambridge University Press.

[27] Lane, Philip and Aaron Tornell (1996) Power, Growth and the Voracity Effect, Journal of Economic Growth 1, 213-241.

[28] Levy-Yeyati, Eduardo and Federico Sturzenegger (2005) Classifying Exchange Rate Regimes: Deeds vs. Words, European Economic Review 49, 1603-1635.

[29] Litan, Robert and Benn Steil (2006) Financial Statecraft: The Role of Financial Markets in American Foreign Policy, New Haven: Yale University Press.

[30] Lohmann, Susanne (1992) Optimal Commitment in Monetary Policy: Credibility versus Flexibility, American Economic Review 82, 273-286.

[31] Masson, Paul and Catherine Pattillo (2005) The Monetary Geography of Africa, Washington: Brookings.

[32] Meissner, Christopher and Nienke Oomes (2008) Why Do Countries Peg the Way They Peg? The Determinants of Anchor Currency Choice, Journal of International Money and Finance, forthcoming.

[33] Phelps, Edmund (1973) Inflation in the Theory of Public Finance, Swedish Journal of Economics 75, 67-82.

[34] Reinhart, Carmen and Kenneth Rogoff (2004) The Modern History of Exchange Rate Arrangements: A Reinterpretation, Quarterly Journal of Economics 119, 1-48.

[35] Rogoff, Kenneth (1985) The Optimal Degree of Commitment to an Intermediate Monetary Target, Quarterly Journal of Economics 100, 11691189. 
[36] Rogoff, Kenneth, Aasim Husain, Ashoka Mody, Robin Brooks, and Nienke Oomes (2004) Evolution and Performance of Exchange Rate Regimes, IMF Occasional Paper 229.

[37] Siklos, Pierre (2002) The Changing Face of Central Banking, Cambridge: Cambridge University Press.

[38] Sturm, Michael and Nikolaus Siegfried (2005) Regional Monetary Integration in the Member States of the Gulf Cooperation Council, European Central Bank Occasional Paper Series 31.

[39] Tornell, Aaron and Andres Velasco (2000) Fixed Versus Flexible Exchange Rates: Which Provides More Fiscal Discipline?, Journal of Monetary Economics 45, 399-436.

[40] Transparency International (2008) Corruption Perception Index. (Available at http://www.transparency.org.)

[41] van der Ploeg, Frederick (2006) Challenges and Opportunities for Resource Rich Economies, CEPR Discussion Paper. 5688.

[42] Vegh, Carlos (1989) Government Spending and Inflationary Finance: A Public Finance Approach, IMF Staff Papers 36, 657-677.

[43] Velasco, Andres (1996) Fixed Exchange Rates: Credibility, Flexibility and Multiplicity, European Economic Review 40, 1023-1035. 


\section{CESifo Working Paper Series}

for full list see www.cesifo-group.org/wp

(address: Poschingerstr. 5, 81679 Munich, Germany, office@cesifo.de)

2497 Scott Alan Carson, Nineteenth Century Black and White US Statures: The Primary Sources of Vitamin D and their Relationship with Height, December 2008

2498 Thomas Crossley and Mario Jametti, Pension Benefit Insurance and Pension Plan Portfolio Choice, December 2008

2499 Sebastian Hauptmeier, Ferdinand Mittermaier and Johannes Rincke, Fiscal Competition over Taxes and Public Inputs: Theory and Evidence, December 2008

2500 Dirk Niepelt, Debt Maturity without Commitment, December 2008

2501 Andrew Clark, Andreas Knabe and Steffen Rätzel, Boon or Bane? Others' Unemployment, Well-being and Job Insecurity, December 2008

2502 Lukas Menkhoff, Rafael R. Rebitzky and Michael Schröder, Heterogeneity in Exchange Rate Expectations: Evidence on the Chartist-Fundamentalist Approach, December 2008

2503 Salvador Barrios, Harry Huizinga, Luc Laeven and Gaëtan Nicodème, International Taxation and Multinational Firm Location Decisions, December 2008

2504 Andreas Irmen, Cross-Country Income Differences and Technology Diffusion in a Competitive World, December 2008

2505 Wenan Fei, Claude Fluet and Harris Schlesinger, Uncertain Bequest Needs and LongTerm Insurance Contracts, December 2008

2506 Wido Geis, Silke Uebelmesser and Martin Werding, How do Migrants Choose their Destination Country? An Analysis of Institutional Determinants, December 2008

2507 Hiroyuki Kasahara and Katsumi Shimotsu, Sequential Estimation of Structural Models with a Fixed Point Constraint, December 2008

2508 Barbara Hofmann, Work Incentives? Ex Post Effects of Unemployment Insurance Sanctions - Evidence from West Germany, December 2008

2509 Louis Hotte and Stanley L. Winer, The Demands for Environmental Regulation and for Trade in the Presence of Private Mitigation, December 2008

2510 Konstantinos Angelopoulos, Jim Malley and Apostolis Philippopoulos, Welfare Implications of Public Education Spending Rules, December 2008

2511 Robert Orlowski and Regina T. Riphahn, The East German Wage Structure after Transition, December 2008 
2512 Michel Beine, Frédéric Docquier and Maurice Schiff, International Migration, Transfers of Norms and Home Country Fertility, December 2008

2513 Dirk Schindler and Benjamin Weigert, Educational and Wage Risk: Social Insurance vs. Quality of Education, December 2008

2514 Bernd Hayo and Stefan Voigt, The Relevance of Judicial Procedure for Economic Growth, December 2008

2515 Bruno S. Frey and Susanne Neckermann, Awards in Economics - Towards a New Field of Inquiry, January 2009

2516 Gregory Gilpin and Michael Kaganovich, The Quantity and Quality of Teachers: A Dynamic Trade-off, January 2009

2517 Sascha O. Becker, Peter H. Egger and Valeria Merlo, How Low Business Tax Rates Attract Multinational Headquarters: Municipality-Level Evidence from Germany, January 2009

2518 Geir H. Bjønnes, Steinar Holden, Dagfinn Rime and Haakon O.Aa. Solheim, ,Large’ vs. ,Small' Players: A Closer Look at the Dynamics of Speculative Attacks, January 2009

2519 Jesus Crespo Cuaresma, Gernot Doppelhofer and Martin Feldkircher, The Determinants of Economic Growth in European Regions, January 2009

2520 Salvador Valdés-Prieto, The 2008 Chilean Reform to First-Pillar Pensions, January 2009

2521 Geir B. Asheim and Tapan Mitra, Sustainability and Discounted Utilitarianism in Models of Economic Growth, January 2009

2522 Etienne Farvaque and Gaël Lagadec, Electoral Control when Policies are for Sale, January 2009

2523 Nicholas Barr and Peter Diamond, Reforming Pensions, January 2009

2524 Eric A. Hanushek and Ludger Woessmann, Do Better Schools Lead to More Growth? Cognitive Skills, Economic Outcomes, and Causation, January 2009

2525 Richard Arnott and Eren Inci, The Stability of Downtown Parking and Traffic Congestion, January 2009

2526 John Whalley, Jun Yu and Shunming Zhang, Trade Retaliation in a Monetary-Trade Model, January 2009

2527 Mathias Hoffmann and Thomas Nitschka, Securitization of Mortgage Debt, Asset Prices and International Risk Sharing, January 2009

2528 Steven Brakman and Harry Garretsen, Trade and Geography: Paul Krugman and the 2008 Nobel Prize in Economics, January 2009 
2529 Bas Jacobs, Dirk Schindler and Hongyan Yang, Optimal Taxation of Risky Human Capital, January 2009

2530 Annette Alstadsæter and Erik Fjærli, Neutral Taxation of Shareholder Income? Corporate Responses to an Announced Dividend Tax, January 2009

2531 Bruno S. Frey and Susanne Neckermann, Academics Appreciate Awards - A New Aspect of Incentives in Research, January 2009

2532 Nannette Lindenberg and Frank Westermann, Common Trends and Common Cycles among Interest Rates of the G7-Countries, January 2009

2533 Erkki Koskela and Jan König, The Role of Profit Sharing in a Dual Labour Market with Flexible Outsourcing, January 2009

2534 Tomasz Michalak, Jacob Engwerda and Joseph Plasmans, Strategic Interactions between Fiscal and Monetary Authorities in a Multi-Country New-Keynesian Model of a Monetary Union, January 2009

2535 Michael Overesch and Johannes Rincke, What Drives Corporate Tax Rates Down? A Reassessment of Globalization, Tax Competition, and Dynamic Adjustment to Shocks, February 2009

2536 Xenia Matschke and Anja Schöttner, Antidumping as Strategic Trade Policy Under Asymmetric Information, February 2009

2537 John Whalley, Weimin Zhou and Xiaopeng An, Chinese Experience with Global 3G Standard-Setting, February 2009

2538 Claus Thustrup Kreiner and Nicolaj Verdelin, Optimal Provision of Public Goods: A Synthesis, February 2009

2539 Jerome L. Stein, Application of Stochastic Optimal Control to Financial Market Debt Crises, February 2009

2540 Lars P. Feld and Jost H. Heckemeyer, FDI and Taxation: A Meta-Study, February 2009

2541 Philipp C. Bauer and Regina T. Riphahn, Age at School Entry and Intergenerational Educational Mobility, February 2009

2542 Thomas Eichner and Rüdiger Pethig, Carbon Leakage, the Green Paradox and Perfect Future Markets, February 2009

2543 M. Hashem Pesaran, Andreas Pick and Allan Timmermann, Variable Selection and Inference for Multi-period Forecasting Problems, February 2009

2544 Mathias Hoffmann and Iryna Shcherbakova, Consumption Risk Sharing over the Business Cycle: the Role of Small Firms' Access to Credit Markets, February 2009 
2545 John Beirne, Guglielmo Maria Caporale, Marianne Schulze-Ghattas and Nicola Spagnolo, Volatility Spillovers and Contagion from Mature to Emerging Stock Markets, February 2009

2546 Ali Bayar and Bram Smeets, Economic and Political Determinants of Budget Deficits in the European Union: A Dynamic Random Coefficient Approach, February 2009

2547 Jan K. Brueckner and Anming Zhang, Airline Emission Charges: Effects on Airfares, Service Quality, and Aircraft Design, February 2009

2548 Dolores Messer and Stefan C. Wolter, Money Matters - Evidence from a Large-Scale Randomized Field Experiment with Vouchers for Adult Training, February 2009

2549 Johannes Rincke and Christian Traxler, Deterrence through Word of Mouth, February 2009

2550 Gabriella Legrenzi, Asymmetric and Non-Linear Adjustments in Local Fiscal Policy, February 2009

2551 Bruno S. Frey, David A. Savage and Benno Torgler, Surviving the Titanic Disaster: Economic, Natural and Social Determinants, February 2009

2552 Per Engström, Patrik Hesselius and Bertil Holmlund, Vacancy Referrals, Job Search, and the Duration of Unemployment: A Randomized Experiment, February 2009

2553 Giorgio Bellettini, Carlotta Berti Ceroni and Giovanni Prarolo, Political Persistence, Connections and Economic Growth, February 2009

2554 Steinar Holden and Fredrik Wulfsberg, Wage Rigidity, Institutions, and Inflation, February 2009

2555 Alexander Haupt and Tim Krieger, The Role of Mobility in Tax and Subsidy Competition, February 2009

2556 Harald Badinger and Peter Egger, Estimation of Higher-Order Spatial Autoregressive Panel Data Error Component Models, February 2009

2557 Christian Keuschnigg, Corporate Taxation and the Welfare State, February 2009

2558 Marcel Gérard, Hubert Jayet and Sonia Paty, Tax Interactions among Belgian Municipalities: Does Language Matter?, February 2009

2559 António Afonso and Christophe Rault, Budgetary and External Imbalances Relationship: A Panel Data Diagnostic, February 2009

2560 Stefan Krasa and Mattias Polborn, Political Competition between Differentiated Candidates, February 2009

2561 Carsten Hefeker, Taxation, Corruption and the Exchange Rate Regime, February 2009 